\title{
UANG ELEKTRONIK DALAM PERSPEKTIF ISLAM
}

\author{
M Rizky Wady Abdulfattah dan \\ Rachmat Rizky Kurniawan ${ }^{1,5}$
}

\author{
${ }^{1,2}$ Afiliasi: Sekolah Tinggi Ekonomi Islam SEBI. \\ Email:wadyaf2@gmail.com,Rah.rizqy@gmail.com
}

\begin{abstract}
ABSTRAK: Kemajuan teknologi dalam sistem pembayaran menggeser peranan uang tunai sebagai alat pembayaran ke dalam bentuk pembayaran non tunai yang lebih efisien dan ekonomis. Uang elektronik muncul sebagai jawaban atas kebutuhan masyarakat terhadap instrumen pembayaran mikro yang diharapkan mampu melakukan proses pembayaran secara lebih cepat, efisien, dan aman dengan biaya yang relatif lebih murah, namun belum semua uang elektronik yang diterbitkan sudah sesuai dengan konsep syariah. Penelitian ini bertujuan untuk mengetahui uang elektronik dalam prespektif islam pada akad dan prinsip syariah yang diterapkan pada transaksi uang elektronik. Penelitian ini menggunakan metode deskriptif dengan penulisan menggunakan metode studi pustaka, yaitu mengkaji teori, sistem, dan cara kerja uang elektronik sehingga dapat ditemukan hubungan hukum dan ketentuan dalam transaksi uang elektronik. Penulisan ini menghasilkan informasi mengenai hukum akad dan prinsip syariah dalam transaksi yang ada pada uang elektronik.
\end{abstract}

Kata Kunci : Uang Elektronik, Transaksi, Akad dan Prinsip

\begin{abstract}
Payment system into non-cash payment form is more efficient and economical. Electronic money arises as an answer to the community's need for a micro payment instrument that is expected to make the payment process faster, more efficient and safer at a relatively cheaper cost, but not all electronic money issued in accordance with the concept of sharia. This study is intended to find out electronic money in Islamic perspective on the contract and sharia principles applied to electronic money transactions. This research uses descriptive method using library learning method, that is studying theory, system, and how to work electronic money so that can found the relation of law and provision in electronic money transaction. This writing produces information about the legal contract and sharia principles in transactions that exist in electronic money.
\end{abstract}

Keywords: Electronic Money, Transactions, Agreements and Principles

\section{PENDAHULUAN}

Memasuki abad millenium, perkembangan teknologi dan informasi begitu cepat dan berdampak pada banyak bidang. Otomotif, komunikasi, dan banyak bidang lainnya tidak terkecuali perekonomian terkhusus pada sistem pembayaran. Kemajuan teknologi dalam sistem pembayaran menggeser peranan uang tunai (currency) sebagai alat 
Jurnal Ekonomi dan Perbankan Syariah

Vol. 6. No.1, April 2018: 90-106, ISSN (cet): 2355-1755 | ISSN (online): 2579-

6437

\section{| 85}

pembayaran ke dalam bentuk pembayaran non tunai yang lebih efisien dan ekonomis (Pramono \& Yanuarti, 2006). Hal ini didukung dengan semakin banyaknya perusahaan-perusahaan ataupun pusat perbelanjaan di Indonesia yang menerima transaksi pembayaran dengan menggunakan sistem pembayaran non tunai. Dengan proses tranksaksi cepat, aman, nyaman, mudah dan efisien merupakan alasan masyarakat Indonesia memiliki respon yang besar terhadap sistem pembayaran non tunai dan sistem pembayaran non tunai ini telah dikembangkan oleh pihak bank maupun non bank sebagai lembaga penyelenggara sistem pembayaran di Indonesia.

Beberapa instrumen pembayaran non tunai yang berkembang di masyarakat sekarang ini, selain yang umum diketahui seperti kartu kredit, kartu debit, kartu ATM, kartu prabayar, dan e-banking (Bank Indonesia, 2004). Isu paling sentral dalam studi mengenai sistem pembayaran elektronik adalah inovasi pembayaran eleketronik berbasis kartu, terutama Alat Pembayaran dengan Menggunakan Kartu (APMK) dan Uang Elektronik (e-money).

Alat Pembayaran dengan Menggunakan Kartu (APMK) adalah seluruh instrumen sistem pembayaran yang pada umumnya berbasis kartu antara lain kartu Anjungan Tunai Mandiri (ATM), kartu kredit, kartu debit, serta jenis kartu lain yang dapat digunakan sebagai alat pembayaran seperti misalnya kartu smart, $e$-wallet, serta beberapa alat pembayaran lain yang dapat dipersamakan dengan kartu (Bank Indonesia, 2005b). Tetapi pembayaran elektronik ini masih selalu terkait dengan rekening nasabah bank yang menggunakannya.

Dalam perkembangannya, beberapa negara telah menemukan dan menggunakan produk pembayaran elektronik yang dikenal sebagai uang elektronik (e-money), yang karakteristiknya berbeda dengan pembayaran elektronis yang telah disebutkan sebelumnya APMK (kartu ATM, kartu debit dan kartu kredit). E- money tidak memerlukan proses otorisasi dan keterkaitan langsung (online) dengan rekening nasabah di bank karena uang elektronik merupakan produk (stored value) yaitu penyimpan nilai dana tertentu (monetary value) telah tersimpan dalam alat pembayaran yang digunakan (Pramono \& Yanuarti, 2006). Berikut grafik perkembangan uang elektronik yang beredar (dalam juta rupiah) 


\section{Grafik 1 Perkembangan Uang Elektronik yang Beredar (dalam juta rupiah)}

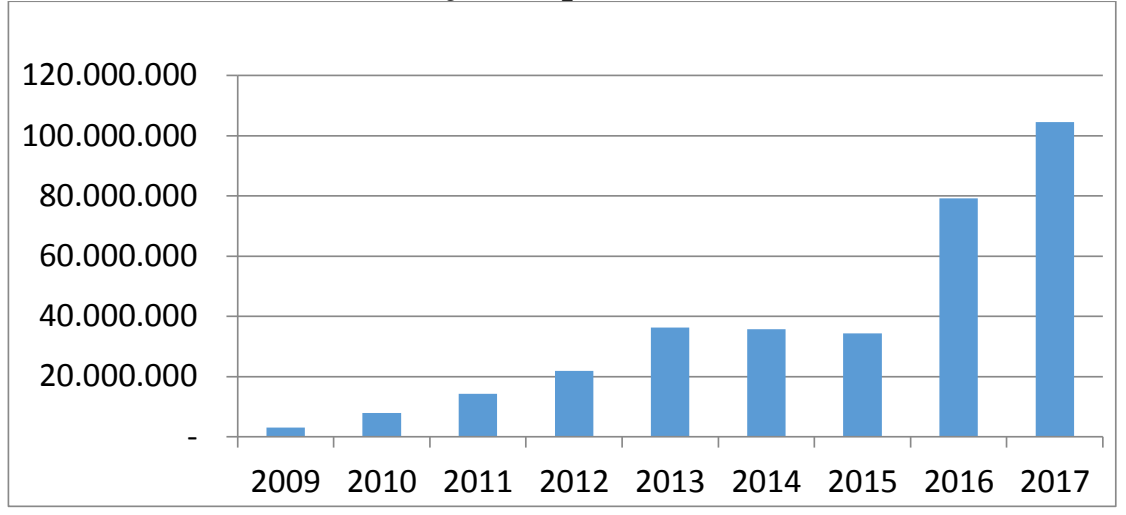

Berdasarkan statistik yang dipublikasikan Bank Indonesia pada November 2017, perkembangan uang elektronik di Indonesia berkembang pesat dari mulai perkembangannya pada tahun 2009 . Tercatat dari tahun 2009, produk uang elektronik yang beredar meningkat sebesar 37,7x lipat sampai dengan bulan November 2017, yang setiap tahunnya terus mengalami peningkatan dan peningkatan yang paling drastis terjadi pada tahun 2016 dan 2017. Hali ini menunjukan bahwa produk ini semakin diminati oleh masyarakat di Indonesia yang semakin berbasis kepada teknologi informasi dalam dunia keuangan.

Hal ini membuktikan bahwa produk uang elektronik merupakan sesuatu yang dipandang sangat penting bagi masyarakat Indonesia saat ini. Beberapa kebijakan pemerintah, Bank Indonesia, maupun perusahaan jasa transportasi Indonesia ikut menggalakkan penggunaan uang elekronik ini. Kebijakan Bank Indonesia yang menggalakkan produk uang elektronik ini adalah Peraturan Bank Indonesia (PBI) Nomor 11 Tahun 2009 tentang Uang Elektronik dan Surat Edaran Bank Indonesia (SEBI) tahun 2009 tentang Uang Elektronik (electronic money).

Penggunaan uang elektronik sebagai alternatif alat pembayaran non cash menunjukkan adanya potensi yang cukup besar untuk mengurangi tingkat pertumbuhan penggunaan uang cash. Uang elektronik menawarkan transaksi yang lebih cepat dan nyaman dibandingkan dengan uang cash, khususnya untuk transaksi yang bernilai kecil (micro payment), sebab dengan uang elektronik transaksi tersebut dapat dilakukan dengan lebih mudah dan murah serta 
Jurnal Ekonomi dan Perbankan Syariah

Vol. 6. No.1, April 2018: 90-106, ISSN (cet): 2355-1755 | ISSN (online): 2579-

6437

| 87

menjamin keamanan dan kecepatan transaksi, baik bagi konsumen maupun bagi pedagang (Hidayati \& Nuryanti, 2006).

Maka dari itu Uang Elektronik tersebut perlu mendapatkan kajian syariah, baik mengenai pengelolaan dana float pada uang elektronik, prinsip-prinsip Syariah yang harus diutamakan dalam transaksi uang elektronik dan konsep akad yang diterapkan pada uang elektronik. Dengan mengacu atas apa yang telah peneliti jelaskan di latar belakang, maka peneliti tertarik untuk mengkaji uang elektronik dalam hukum islam dengan judul penelitian : "Uang Elektronik dalam Prespektif Islam".

\section{LANDASAN TEORI}

\subsection{Pengertian Uang Elektronik}

Menurut Peraturan Bank Indonesia Nomor: 11/12/PBI/2009 Tentang Uang Elekronik, uang elektronik adalah alat pembayaran yang diterbitkan atas dasar nilai uang yang disetor dahulu oleh pemegang kepada penerbit, yang tersimpan secara elektronik dalam suatu media seperti server atau chip, dan nilai uang tersebut bukan merupakan simpanan serta digunakan sebagai alat pembayaran kepada pedagang yang bukan merupakan penerbit uang elektronik tersebut.

\subsection{Manfaat Uang Elektronik}

Sistem pembayaran mikro mengalami perkembangan cukup pesat di berbagai negara dewasa ini, seiring dengan perkembangan teknologi dan kebutuhan masyarakat untuk menggunakan alat pembayaran yang mudah, aman dan efisien. Instrumen pembayaran mikro adalah instrumen pembayaran yang didesain untuk menangani kebutuhan transaksi dengan nilai yang kecil namun dengan volume yang tinggi serta membutuhkan waktu pemerosesan transaksi yang relatif lebih cepat (Tim Inisiatif BI 2006, 2006, p. 4).

Kebutuhan instrumen pembayaran mikro timbul karena apabila pembayaran dilakukan menggunakan intrumen pembayaran yang ada saat ini, seperti uang tunai, kartu kredit, dan kartu debit dan sebagainya menjadi kurang praktis dan efisien. Uang elektronik muncul sebagai jawaban atas kebutuhan terhadap instrumen pembayaran mikro yang diharapkan mampu melakukan proses pembayaran secara cepat dengan biaya yang relatif murah karena pada umumnya nilai uang yang disimpan instrumen ini ditempatkan pada suatu tempat tertentu yang 
mampu diakses cepat secara off-line, aman dan murah (Tim Inisiatif BI 2006, 2006, p. 8).

Beberapa manfaat dari penggunaan uang elektronik (Hidayati \& Nuryanti, 2006, p. 5) :

1. Penggunaan dalam pembayaran sangat mudah, cukup tempelkan kartu maupun transaksi secara mobile untuk bertransaksi tanpa repot akan uang kembalian.

2. Dapat meminimalkan penggunaan uang kertas sehingga meminimalisir kerusakan fisik uang yang beredar, meminimalisir peredaran uang palsu, dan meminimalisir resiko pencurian.

3. Sangat baik untuk pembayaran massal yang bernilai kecil namun frekuensinya tinggi seperti pembayaran jalan tol, parkir, transportasi dan lain-lain.

\subsection{Akad Dalam Islam}

Akad berasal dari bahasa Arab, yaitu dari kata "al- 'aqd" Kata tersebut merupakan bentuk mashdar yang berarti menyimpulkan, membuhul tali, perjanjian, persetujuan, penghitungan, mengadakan pertemuan. Akad da lam bahasa Indonesia dikenal dengan istilah perjanjian, perikatan, atau kontrak. Perjanjian berarti suatu peristiwa yang mana seseorang berjanji kepada orang lain atau pihak lain (perorangan maupun badan hukum) atau suatu peristiwa yang mana dua orang atau pihak saling berjanji untuk melakukan suatu hal (Rahmawati, 2011, p. 21).

\section{A. Wadi'ah}

Secara istilah wadi'ah berarti mewakilkan penjagaan suatu harta yang spesial atau bernilai tertentu dengan cara tertentu. Dikutip oleh ath-Thayyar dkk., al-Bahuti Mansyur mendefinisikan wadi'ah sebagai pemberian kuasa oleh penitip kepada orang yang menjaga hartanya tanpa kompensasi. Menurut Sjahdeini, Akad wadi'ah merupakan suatu akad yang bersifat tolong-menolong antar sesama manusia. Yaitu tolong-menolong dalam hal menyempurnkan amanat (Afif, 2013, p. 87).

\section{a. Rukun Wadi'ah}

Rukun Wadi'ah adalah sebagai berikut :

1. Muwaddi (orang yang menitipkan)

2. Wadi' (orang yang dititipi barang)

3. Wadi'ah (barang yang dititipkan)

4. Shigot (ijab dan qabul) 
Jurnal Ekonomi dan Perbankan Syariah

Vol. 6. No.1, April 2018: 90-106, ISSN (cet): 2355-1755 | ISSN (online): 2579-

6437

89

\section{b. Syarat Wadi'ah}

Ulama Madzhab Hanafiyah mensyaratkan bahwa dua orang yang melakukan akad wadi'ah harus berakal sehat. Maka tidak sah jika akad yang dilakukan oleh anak kecil yang belum bisa membedakan antara yang "baik dan buruk" atau belum faham "benar dan salah". Demikian juga yang dilakukan oleh orang gila. Kedewasaan (baligh) tidak menjadi syarat sah wadi'ah menurut ulama Madzhab Hanafiyah. Menurut jumhur ulama, pelaku perjanjian wadi'ah harus baligh, berakal sehat dan cakap (sanggup melakukan transaksi tersebut). Syarat harta yang dititipkan harus berupa benda yang bisa dititipkan dan dijaga. Bukan dikatakan sebagai barang titipan jika harta itu berupa burung yang masih terbang bebas di langit atau harta yang tenggelam di dasar laut (Afif, 2014, p. 254).

\section{B. Ijarah}

Al-ijarah berasal dari kata al-ajru, yang berarti al-iwadhu (ganti). Menurut pengertian syara, al-ijarah adalah suatu jenis akad untuk mengambil manfaat dengan jalan pengganti. Al-ijarah adalah akad pemindahan hak guna atas barang atau jasa melalui pembayaran upah sewa, tanpa diikuti dengan pemindahan kepemilikan (ownership/milkiyyah) atas barang itu sendiri (Santoso \& Anik, 2015, p. 107).

Menurut Fatwa Dewan Syarah Nasional No.09/DSN/MUI/IV/2000, Ijarah merupakan akad pemindahan hak guna (manfaat) atas suatu barang atau jasa dalam waktu tertentu melalui pembayaran sewa/upah, tanpa diikuti dengan pemindahan kepemilikan barang itu sendiri, dengan demikian dalam akad ijarah tidak ada perubahan kepemilikan, tetapi hanya pemindahan hak guna saja dari yang menyewakan kepada penyewa (Santoso \& Anik, 2015, p. 107).

a. Rukun Ijarah

1. Pelaku akad, yaitu mustajir (penyewa), adalah pihak yang menyewa aset dan mu'jir/muajir (pemilik) adalah pihak pemilik yang menyewakan aset.

2. Objek akad, yaitu ma'jur (aset yang disewakan) dan ujrah (harga sewa).

3. Sighat yaitu ijab dan qabul.

\section{b. Syarat Ijarah}

1. Jasa atau manfaat yang akan diberikan oleh aset yang disewakan tersebut harus tertentu dan diketahui dengan jelas oleh kedua belah pihak. 
2. Kepemilikan aset tetap pada yang menyewakan yang bertanggung jawab pemeliharaannya, sehingga aset tersebut harus dapat memberi manfaat kepada penyewa.

3. Akad ijarah dihentikan pada saat aset yang bersangkutan berhenti.

4. Memberikan manfaat kepada penyewa. Jika aset tersebut rusak dalam periode kontrak, akad ijarah masih tetap berlaku.

\section{Wakalah}

Wakalah berasal dari wazan wakala-yakilu-waklan yang berarti menyerahkan atau mewakilkan urusan sedangkan wakalah adalah pekerjaan wakil Al-Wakalah juga berarti penyerahan (al Tafwidh) dan pemeliharaan (al-Hifdh). Menurut kalangan syafi'iyah arti wakalah adalah ungkapan atau penyerahan kuasa (al-muwakkil) kepada orang lain (al-wakil) supaya melaksanakan sesuatu dari jenis pekerjaan yang bisa digantikan (an-naqbalu an-niyabah) dan dapat di lakukan oleh pemberi kuasa, dengan ketentuan pekerjaan tersebut di laksanakan pada saat pemberi kuasa masih hidup (Nuhyatia, 2013, p. 95).

Wakalah dalam arti harfiah adalah menjaga, menahan atau penerapan keahlian atau perbaikan atas nama orang lain, dari sini kata Tawkeel diturunkan yang berarti menunjuk seseorang untuk mengambil alih atas suatu hal juga untuk mendelegasikan tugas apapun ke orang lain. Akad Wakalah adalah akad yang memberikan kuasa kepada pihak lain untuk melakukan suatu kegiatan dimana yang memberi kuasa tidak dalam posisi melakukan kegiatan tersebut. Akad wakalah pada hakikatya adalah akad yang digunakan oleh seseorang apabila dia membutuhkan orang lain atau mengerjakan sesuatu yang tidak dapat dilakukannya sendiri dan meminta orang lain untuk melaksanakannya (Nuhyatia, 2013, p. 96).

\section{a. Rukun dan Syarat Wakalah}

Menurut kelompok Hanafiah, rukun wakalah itu hanya ijab qabul. Ijab merupakan pernyataan mewakilkan sesuatu dari pihak yang memberi kuasa dan qabul adalah penerimaan pendelegasian itu dari pihak yang diberi kuasa tanpa harus terkait dengan menggunakan sesuatu lafaz tertentu. Akan tetapi, mayoritas ulama tidak sependirian dengan pandangan tersebut. Mereka berpendapat bahwa rukun dan syarat wakalah itu adalah sebagai berikut (Purnama, 2012, p. 97):

a) Orang yang mewakilkan (Al-Muwakkil)

a. Seseorang yang mewakilkan, pemberi kuasa, disyaratkan memiliki hak untuk ber-tasarruf pada bidang-bidang yang didelegasikannya. Karena itu seseorang tidak akan sah jika mewakilkan sesuatu yang bukan haknya,

b. Pemberi kuasa mempunyai hak atas sesuatu yang dikuasakannya, disisi lain juga dituntut supaya pemberi kuasa itu sudah cakap bertindak atau 
Jurnal Ekonomi dan Perbankan Syariah

Vol. 6. No.1, April 2018: 90-106, ISSN (cet): 2355-1755 | ISSN (online): 2579-

6437

91

mukallaf. Tidak boleh seorang pemberi kuasa itu masih belum dewasa yang cukup akal serta pula tidak boleh seorang yang gila. Menurut pandangan Imam Syafi'i anak-anak yang sudah mumayyiz tidak berhak memberikan kuasa atau mewakilkan sesuatu kepada orang lain secara mutlak. Namun madzhab Hambali membolehkan pemberian kuasa dari seorang anak yang sudah mumayyiz pada bidang-bidang yang akan dapat mendatangkan manfaat baginya.

b) Orang yang diwakilkan (Al-Wakil)

a. Penerima kuasa pun perlu memiliki kecakapan akan suatu aturanaturan yang mengatur proses akad wakalah ini. Sehingga cakap hukum menjadi salah satu syarat bagi pihak yang diwakilkan.

b. Seseorang yang menerima kuasa ini, perlu memiliki kemampuan untuk menjalankan amanahnya yang diberikan oleh pemberi kuasa. Ini berarti bahwa ia tidak diwajibkan menjamin sesuatu yang diluar batas, kecuali atas kesengajaan yang ia perbuat.

c) Obyek yang diwakilkan

a. Obyek mestilah sesuatu yang bisa diwakilkan kepada orang lain, seperti jual beli, pemberian upah, dan sejenisnya yang memang berada dalam kekuasaan pihak yang memberikan kuasa.

b. Para ulama berpendapat bahwa tidak boleh menguasakan sesuatu yang bersifat ibadah badaniyah, seperti shalat, dan boleh menguasakan sesuatu yang bersifat ibadah maliyah seperti membayar zakat, sedekah, dan sejenisnya.

c. Tidak semua hal dapat diwakilkan kepada orang lain. Sehingga obyek yang akan diwakilkan pun tidak diperbolehkan bila melanggar syariat Islam.

d) Lafaz Akad (Sighah)

a. Dirumuskannya suatu perjanjian antara pemberi kuasa dengan penerima kuasa. Dari mulai aturan memulai akad wakalah ini, proses akad, serta pasal yang mengatur berakhirnya akad wakalah ini.

b. Isi dari perjanjian ini berupa pendelegasian dari pemberi kuasa kepada penerima kuasa.

c. Tugas penerima kuasa oleh pemberi kuasa perlu dijelaskan untuk dan atas pemberi kuasa melakukan sesuatu tindakan tertentu.

\section{HASIL DAN ANALISIS}

A. Penerbitan dan Pengisian Nilai Uang Elektronik dalam Prespektif Islam

Dalam penerbitan uang elektronik terdapat pihak-pihak yang terlibat sebagai penyelenggara uang elektronik terdiri dari prinsipal, penerbit, acquirer, penyelenggara kliring dan penyelenggara penyelesaian akhir. 
Penerbit menempati posisi yang paling penting dalam hubungan antar penyelenggara uang elektronik tersebut, baik dilihat dari sisi kebijakan Bank Sentral karena penerbit sebagai pihak yang menerbitkan uang elektronik sebagai alat pembayaran, maupun dilihat dari sisi antar penyelenggara karena penerbit yang mengelola dana float dan mendapat keuntungan dari outstanding dana float tersebut. Akad yang terbangun dari hubungan antar penyelenggara uang elektronik dapat menggunakan akad Ijarah, dimana pihak-pihak yang memberikan jasa atau sewa dimungkinkan untuk mendapatkan ujroh atas pelayanan jasa atau sewa yang diberikannya.

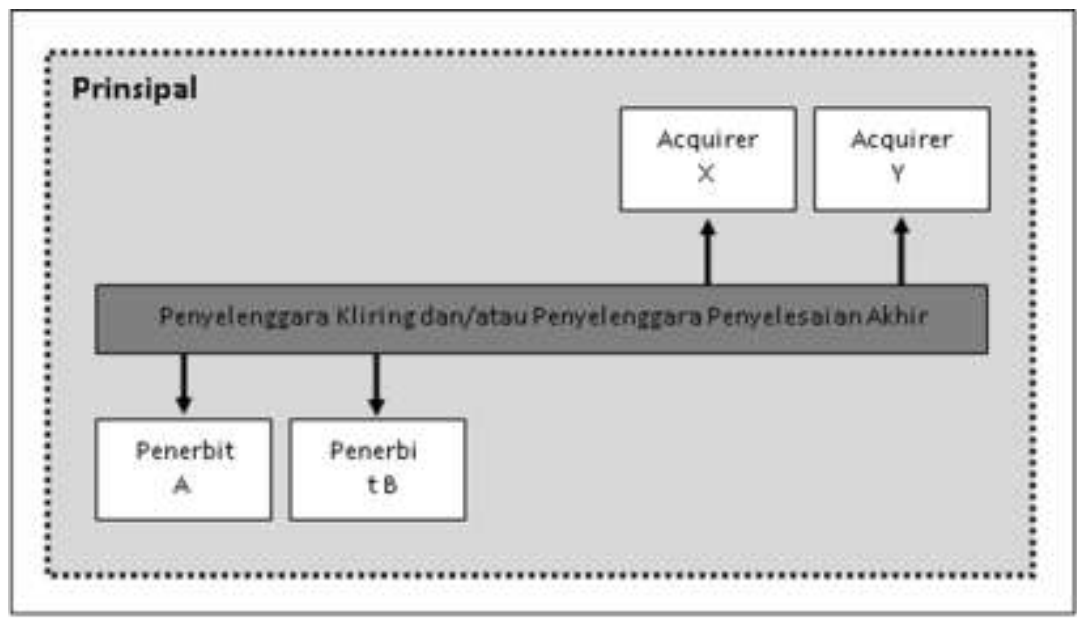

Ketereangan :

c. Prinsipal adalah pihak yang bertanggung jawab atas pengelolaan sistem atau jaringan yang digunakan oleh penerbit, acquirer, penyelenggara kliring dan penyelenggara penyelesaian akhir dalam transaksi uang elektronik. Dalam hal ini, prinsipal dimungkinkan mendapat imbal (ujroh) atas penggunaan sistem atau jaringan yang dikelolanya.

d. Penyelenggara kliring atau penyelenggara penyelesaian akhir adalah pihak yang melakukan perhitungan hak dan kewajiban keuangan masingmasing penerbit dan acquirer serta bertanggungjawab untuk melakukan penyelesaian akhir (sattlement) atas hak dan kewajiban keuangan masingmasing tersebut dalam rangka transaksi uang elektronik. Karena itu, penyelenggara kliring atau penyelenggara penyelesaian akhir dimungkinkan dapat memperoleh imbalan (ujroh) atas pelayanan jasa yang diberikan tersebut.

e. Hubungan yang terjadi antara penerbit dengan acquirer adalah sematamata hubungan bisnis yang tiap pihak bertindak secara sendiri-sendiri untuk kepentingan tertentu. Hubungan antara penerbit dengan acquirer sama halnya dengan hubungan antara penerbit dengan pedagang, karena 
Jurnal Ekonomi dan Perbankan Syariah

Vol. 6. No.1, April 2018: 90-106, ISSN (cet): 2355-1755 | ISSN (online): 2579-

6437

93

acquirer adalah pihak yang bekerjasama dengan pedagang yang dapat memproses data uang elektronik dan menampung dana hasil penukaran uang elektronik yang dilakukan pedagang kepada penerbit.

Pada saat penerbitan dan pengisian ulang dilakukan dengan cara pemegang menyetorkan terlebih dahulu sejumlah uang kepada penerbit, baik secara langsung kepada penerbit maupun melalui agenagen penerbit atau pendebitan rekening di bank, dan nilai uang dibayarkan tersebut kemudian dimasukkan menjadi nilai uang elektronik dalam media uang elektronik. Dalam proses penerbitan dan pengisian ulang ini ada tiga pihak yang terlibat yaitu penerbit, pemegang uang elektronik, dan agen-agen penerbit uang elektronik. Berikut akad yang terbangun dalam proses penerbitan dan pengisian uang elektronik :

a. Akad antara Penerbit dengan Pemegang

Penetapan akad transaksi anatara penerbit dengan pemegang bisa menggunakan akad wadi'ah, terjadi ketika calon pemegang uang elektronik menyerahkan sejumlah uang kepada Penerbit dengan maksud menitipkan dan selanjutnya sejumlah uang tersebut dikonversikan menjadi sebuah nilai uang elektronik senilai uang yang diserahkan. Selanjutnya Penerbit wajib memelihara dan menjaga sejumlah uang tersebut dan menyerahkannya kepada pemegang saat diminta atau diambil atau untuk pembayaran kepada pedagang (Merchant).

Dalam hubungan antara penerbit dengan pemegang, tanggung jawab yang mendasar bagi penerbit adalah memberikan jaminan bahwa produk uang elektronik yang dikeluarkannya dapat digunakan sebagai alat pembayaran terhadap pedagang yang bekerja sama dengan penerbit.

Transaksi antara penerbit dengan pemegang dapat dilengkapi dengan akad Ijarah, dimana terdapat pelayanan jasa dan sewa yang dilakukan oleh penerbit, dalam hal tersebut penerbit dapat dimungkinkan untuk memperoleh imbalan jasa (ujroh) atas pelayanan jasa dan sewa yang diberikannya.

b. Akad antara penerbit dan pedagang

Penerbit dapat bekerjasama dengan pedagang sebagai agen penerbit, dalam hubungan ini pedagang menjadi wakil dari penerbit, maka transaksi apapun yang dilakukan lewat pedagang tersebut dan atas nama penerbit, hal tersebut sama halnya penerbit bertindak sendiri. Dalam hubungan tersebut, pedagang dapat dimungkinkan untuk mendapat imbalan dari penerbit atas jasa perwakilan yang dilakukannya, maka dalam hal ini antara penerbit dan pedagang dapat diikat menggunakan akad wakalah.

Pertukaran antara nilai uang tunai dengan nilai uang elektronik harus sama jumlahnya (tamatsul) baik kualitas maupun kuantitasnya, jika jumlahnya tidak sama, maka tergolong ke dalam bentuk riba al-fadl, yaitu tambahan atas salah satu dua barang yang dipertukarkan dalam pertukaran barang ribawi yang sejenis (Al-Zuhaili, 2004). 
Oleh karena itu, dalam proses pengisian ulang tidak boleh melakukan pertukaran nilai uang tunai yang lebih kecil atau lebih besar dari nilai uang elektronik. Sebagai contoh penerbit tidak boleh menjual uang elektronik sebesar Rp 500.000,00 dengan penyetoran uang/dana dari pemegang kepada penerbit sebesar Rp 510.000,00 dan penerbit juga tidak boleh memberikan potongan harga atas penjualan uang elektronik, seperti dengan nilai uang elektronik sebesar Rp 500.000,00 dijual oleh penerbit melalui penyetoran uang/dana dari pemegang kepada penerbit sebesar Rp 490.000,00, kelebihan pembayaran oleh pemegang dan potongan harga oleh penerbit tersebut termasuk riba al-fadl. Apabila ada biaya jasa yang dikeluarkan atas pihak agen dalam membantu menerbitkan uang elektronik maka harus dibayarkan diluar transaksi jumlah nilai uang yang diterbitkan.

\section{B. Transaksi Pembayaran Uang Elektronik dalam Prespektif Islam}

Transaksi pembayaran merupakan fungsi utama pada media uang elektronik untuk memenuhi kebutuhan pemegang dalam mendapatkan manfaat dari media uang elektronik yang dimiliki, pada transaksi pembayaran uang elektronik yang sesuai dengan prinsip syariah harus ada akad yang mengikat antara pihak yang terlibat dalam transaksi dan ketentuan syarat dalam transaksi pembayaran.

\section{Akad antara Pemegang dengan Pedagang}

Transaksi jual beli barang yang dilakukan antara pemegang uang elektronik dengan pedagang merupakan transaksi jual beli tunai. Pembayaran dengan uang elektronik sama hukum dan ketentuannya dengan jual beli barang dengan menggunakan uang tunai (cash), karena pada dasarnya antara uang elektronik dengan uang tunai (cash) terdapat kesamaan fungsi sebagai alat pembayaran. Dalam hal pedagang menjadi agen penerbit dalam hal pengisian ulang, tarik tunai dan transfer dana, maka transaksi apapun yang dilakukan antara pedagang dengan pemegang, pada hakikatnya merupakan transaksi antara pemegang dengan penerbit.

\section{Prinsip Syariah dalam Transaksi Pembayaran Uang Elektronik}

Dalam transaksi pembayaran pada uang elektronik terdapat prinsip-prinsip syariah yang harus diterapkan pada media uang elektronik agar sesuai dengan ketententuan uang elektronik syariah, berikut prinsip yang harus diterapkan pada transaksi pembayaran uang elektronik :

\section{Tidak Mengandung Maysir}

Maysir yaitu transaksi yang di dalamnya mengandung unsur perjudian, untung-untungan atau. Spekulatif yang tinggi (Bank Indonesia, 2005a, p. 4). Penyelenggaraan uang elektronik harus 
Jurnal Ekonomi dan Perbankan Syariah

Vol. 6. No.1, April 2018: 90-106, ISSN (cet): 2355-1755 | ISSN (online): 2579-

6437

| 95

didasarkan oleh kebutuhan pembayaran retail yang menuntut pada transaksi yang lebih cepat dan efisien, tidak untuk kebutuhan transaksi yang mengandung maysir.

"Hai orang-orang yang beriman, Sesungguhnya (meminum) khamar, berjudi, (berkorban untuk) berhala, mengundi nasib dengan panah, adalah Termasuk perbuatan syaitan. Maka jauhilah perbuatanperbuatan itu agar kamu mendapat keberuntungan". (Q.S Al-Maidah [5]:90)

2. Tidak mendorong Israf

Uang elektronik pada dasarnya digunakan sebagai alat pembayaran retail atau mikro, agar terhindar dari Israf (pengeluaran yang berlebihan) dalam konsumsi maka dilakukan pembatasan jumlah nilai uang elektronik dan batas maksimal total nilai transaksi uang elektronik dalam periode tertentu. Sebagaiman firman Allah SWT yang artinya artinya: "Makan dan minumlah, dan janganlah berlebihlebihan. Sesungguhnya Allah tidak menyukai orang-orang yang berlebih-lebihan" (Q.S Al-A'raf [7]:31)

3. Tidak digunkan untuk tansaksi objek haram

Uang elektronik sebagai alat pembayaran dengan menggunakan prinsip Syariah, maka uang elektronik tidak boleh digunakan untuk pembayaran transaksi objek yang mengandung unsur haram dan maksiat, yaitu barang yang dilarang digunakan atau dimanfaatkan menurut hukum Islam (DSN, 2002).

\section{Deposit/Refund dan Collection dalam Prespektif Islam Deposit/Refund}

Guna memastikan redeemability oleh penerbit kepada pemegang kartu maupun merchant, maka perlu ada pengaturan yang jelas mengenai pengelolaan dana float uang elektronik oleh penerbit. Berikut penempatan dana float pada Surat Edaran Bank Indonesia No. 11/11/DASP Perihal Uang Elektronik :

1. Dalam hal Penerbit berupa Lembaga Selain Bank, maka Dana Float yang dikelola wajib ditempatkan pada Bank Umum dalam bentuk rekening simpanan berupa tabungan, giro, dan/atau deposito.

2. Dana Float yang ditempatkan pada Bank Umum sebagaimana dimaksud pada angka 1 sebesar $100 \%$ dari Dana Float yang diperoleh dari hasil penjualan Uang Elektronik yang masih merupakan kewajiban Penerbit kepada Pemegang dan Pedagang. 
3. Dana Float tidak dapat digunakan untuk membiayai kegiatan di luar kewajiban kepada Pemegang dan Pedagang tersebut seperti untuk pembiayaan operasional Penerbit.

4. Pemenuhan kewajiban kepada Pemegang dan Pedagang harus dilakukan oleh Penerbit dengan tepat waktu.

5. Penatausahaan Dana Float milik Penerbit yang berasal dari Bank dilakukan dengan pencatatan pada sisi kewajiban segera atau ruparupa pasiva. Jika Penerbit yang berasal dari Bank tersebut melakukan penempatan Dana Float maka harus dilakukan pada investasi yang aman dan likuid.

\section{A. Hukum Positif}

Dilihat dari penempatan dana float yang di paparkan diatas, pada poin ketiga dijelaskan bahwasannya dana float tidak dapat digunakan untuk mebiayai kegiatatan di luar kewajiban kepada pemegang dan pedagang seperti untuk pembiayaan operasional bank. Maka dilihat dari poin ketiga ini dana float yang ditempatkan pada bank tidak bisa dijadikan sebagai objek utama pada bank untuk megelola dana float sebagai objek yang mengahasilkan keuntungan, dan walaupun dana float itu dikelola maka harus pada ditempatkan pada investasi yang aman dan likuid yang disajikan pada poin kelima yaitu penatausaan dana float milik penerbit yang berasal dari bank dilakukan dengan pencatatan pada sisi kewajiban segera atau rupa-rupa pasiva dan jika penerbit ingin menempatkan dana float maka harus dilakukan pada investasi yang aman dan likuid.

B. Pandangan Fiqh

Menurut (Sahroni, 2017) uang elektronik yang digunakan saat ini mengandung unsur ribawi karena :

1. Kontrak yang terjadi antara pihak-pihak uang elektronik itu tidak jelas (gharar) dan tidak mengikuti transaksi syariah sehingga hak dan kewajiban para pihak tidak bisa diketahui. Karena kontraknya belum jelas maka untuk mengetahui berapa bagi hasil, fee, margin, kewajiban, perpindahan kepemilikan dan yang menanggung resiko, semuanya bisa diketahui apabila identitas akadnya sudah jelas maka dengan mudah bisa menentukan mana yang hak dan kewajiban masing-masing pihak.

2. Bunga atas penempatan dana uang elektronik di bank konvensional sebagai mitra penerbit uang elektronik (lembaga non bank). Karena penerbit bukan lembaga selain bank makan dana float yang dikelola wajib ditempatkan pada bank umum yang bekerjasama dengan penerbit dalam bentuk rekening simpanan berupa tabungan, giro, dan deposito. Oleh karena itu maka keikutsertaan 
Jurnal Ekonomi dan Perbankan Syariah

Vol. 6. No.1, April 2018: 90-106, ISSN (cet): 2355-1755 | ISSN (online): 2579-

6437

197

kita sebagai pemililik kartu dan disimpan di rekening bank konvensional maka penempatan itu akan menghasilkan bunga dan dalam hal ini dapat menguatkan posisi keuangan bank konvensional.

3. Hak pemegang kartu menjadi hilang pada saat kartu yang dimilikinya hilang, padahal dana yang tersimpan adalah milik pemegang uang elektronik. Hal ini terjadi pada jenis uang elektronik chip-based dan unregisted, kerena jenis uang elektronik ini tidak terdaftar pemiliknya di penerbit sama halnya dengan dompet pribadi. Kelebihan chip-based ini lebih cepat dalam transaksi dibanding dengan jenis uang elektronik server-based. Sedangkan kelebihan server-based pemegegang uang elektronik terdaftar pada sistem penerbit, jadi ketika jenis uang elektronik server-based ini hilang maka hak pemegang uang elektronik masih terdaftar di penerbit uang elektonik.

Selain itu, pertukaran antara nilai uang tunai dengan nilai uang elektronik harus dilakukan secara tunai (taqabudh), jika pertukaran tersebut tidak dilakukan secara tunai (taqabudh), maka tergolong ke dalam bentuk riba al-nasiah, yaitu penundaan penyerahan salah satu dua barang yang dipertukarkan dalam jual-beli barang ribawi yang sejenis (Al-Zuhaili, 2004). Sebagai contoh pada saat pemegang atau pedagang menukarkan kembali (refund/redeem) nilai uang elektronik dengan nilai uang tunai kepada penerbit, maka penerbit harus memenuhi hak tagih tersebut dengan tepat waktu tanpa melakukan penangguhan pembayaran.

Dalam hal penerbit membutuhkan waktu untuk proses verifikasi dan perhitungan hak dan kewajiban antara kedua belah pihak terhadap redeem yang dilakukan oleh pedagang, maka hal tersebut diperbolehkan karena dianggap tunai, sedangkan waktu yang dibutuhkan oleh penerbit dianggap sebagai proses penyelesaian yang tidak bisa dihindari.

\section{Collection}

Proses collection yaitu penyetoran electronic value yang diterima oleh merchant dari pengguna uang elektronik kepada penerbit untuk keuntungan rekening merchant. Jadi dalam proses collection ini ada tiga pihak yang terlibat yaitu penerbit, merchant, dan acquirer. Acquirer disini adalah bank atau lembaga selain bank yang bekerjasama dengan pedagang, yang dapat memproses data uang elektronik yang diterbitkan oleh pihak lain (Bank Indonesia, 2009, p. 
4). Maka dalam proses collection terdapat dua skema, yaitu proses melalui kliring dan tanpa kliring.

1. Melalui Kliring

Apabila seseorang melakukan pembayaran pada merchant dimana penerbit uang elektronik dan acquirer merchant adalah institusi yang berbeda, maka tagihan dari merchant tersebut kepada penerbit dapat diambil alih oleh acquirer melalui mekanisme kliring. Maka dalam transaksi ini hubungan antara merchant dengan acquirer dapat menggunakan akad wakalah dimana merchant memberikan kuasa pada acquirer untuk mewakilkannya dalam mekanisme kliring.

2. Tanpa Kliring

Apabila seseorang melakukan pembayaran pada merchant dimana uang elektronik dan acquirer merchant adalah institusi yang sama, maka tagihan dari merchant kepada penerbit/acquirer akan langsung dibayarkan oleh issuerlacquirer yang bersangkutan tanpa melalui mekanisme kliring.

\section{KESIMPULAN}

Penelitian ini bertujuan untuk mengkaji Uang Elektronik dalam Prespektif Islam yang dilihat dari jenis-jenis transaksi uang elektronik pada penerbitan dan pengisian nilai uang, transaksi pembayaran, deposit dan collection. Dari hasil penelitian ini dapat disimpulkan sebagai berikut :

1. Penerbitan dan pengisian nilai uang elektronik

a. Dalam penyelenggaraan uang elektronik akad yang terbangun antar penyelenggara uang elektronik dapat menggunakan akad Ijarah, dimana pihak-pihak yang memberikan jasa atau sewa dimungkinkan untuk mendapatkan ujroh atas pelayanan jasa atau sewa yang diberikannya.

b. Dalam transaksi anatara penerbit dengan pemegang bisa menggunakan akad wadi'ah, terjadi ketika pemegang uang elektronik menyerahkan sejumlah uang kepada penerbit dengan maksud menitipkan dan dikonversikan menjadi sebuah nilai uang elektronik senilai uang yang diserahkan. Dan dalam pengisian nilai uang elektronik tidak boleh ada tambahan nilai uang yang lebih kecil atau lebih besar tanpa keterangan yang jelas, apabila ada tambahan maka termasuk dalam riba fadl.

c. Hubungan antara penerbit dan pedagang dapat diikat menggunakan akad wakalah, dimana pedagang mewakilkan penerbit dalam proses transaksi dengan pengguna uang elektronik. 
Jurnal Ekonomi dan Perbankan Syariah

Vol. 6. No.1, April 2018: 90-106, ISSN (cet): 2355-1755 | ISSN (online): 2579-

6437

| 99

2. Transaksi pembayaran uang elektronik

Transaksi jual beli barang atau jasa antara pemegang uang elektronik dengan pedagang merupakan transaksi jual beli tunai. Pembayaran dengan uang elektronik sama hukum dan ketentuannya dengan jual beli barang dengan menggunakan uang tunai, karena pada dasarnya antara uang elektronik dengan uang tunai terdapat kesamaan fungsi sebagai alat pembayaran.

Prinsip yang harus diterapkan pada transaksi pembayaran uang elektronik

a. Tidak mengandung maysir

b. Tidak mendorong israf

c. Tidak digunakan untuk transaksi objek haram

3. Deposit/refund dan collection, setiap pengelolaan dana float uang elektronik yang di tempatkan pada bank konvensional maka mengandung unsur ribawi. Karena setiap transaksi di bank konvensional merupakan pinjaman berbunga yang diharamkan. Uang elektronik yang sesuai dengan prinsip syariah sesuai DSN MUI wajib ditempatkan pada Bank Syariah. Dan dalam proses collection hubungan antara merchant dengan acquirer dapat menggunakan akad wakalah dimana merchant memberikan kuasa pada acquirer untuk mewakilkan merchant dalam mekanisme kliring.

\section{DAFTAR PUSTAKA}

Afif, M. (2013). Analisis Kritis Implementasi Akad Wadi'ah (Studi Kasus Pada Perbankan Syariah Di Indonesia). Jurnal Ekonomi Islam, vol.2(1), 85-104.

Afif, M. (2014). Implementasi Akad Wadi'ah Atau Qard. Jurnal Hukum Islam, 12, 251-264.

Al-Zuhaili, W. (2004). al-Fiqh al-Islamy wa Adillatuhu.

Bank Indonesia. (2004). Penyelenggaraan Kegiatan Alat Pembayaran dengan Menggunakan Kartu. Peraturan Bank Indonesia Nomor : 6/30/PBI/2004.

Bank Indonesia. (2005a). Akad Penghimpunan dan Penyaluran Dana Bagi Bank yang Melaksanakan Kegiatan Usaha Berdasarkan Prinsip Syariah. Peraturan Bank Indonesia Nomor: 7/46/PBI/2005.

Bank Indonesia. (2005b). Laporan Tahunan Bank Indonesia Tahun 2005 Tentang Alat Pembayaran Non Tunai Elektronik. Bank Indonesia. 
100 | M. Rizky Wady Abdulfattah: Vang Elektronik Dalam Perspektif Islam

Bank Indonesia. (2009). Uang Elektronik (Electronic Money). Peraturan Bank Indonesia Nomor : 11/12/PBI/2009.

DSN. (2002). Jual Beli Mata Uang (Al-Sharf). Fatwa DSN Nomor: 28/DSN-MUI/III/2002.

Hidayati, S., \& Nuryanti, I. (2006). Operasional E-Money. Bank Indonesia, $1-5$.

Nuhyatia, I. (2013). Penerapan dan Aplikasi Akad Wakalah pada Produk Jaksa Bank Syariah. Jurnal Ekonomi Dan Hukum Islam, 3(2), 94-116.

Pramono, B., \& Yanuarti, T. (2006). Dampak Pembayaran Non Tunai Terhadap Perekonomian dan Kebijakan Moneter. Bank Indonesia.

Purnama, D. (2012). Penerapan Akad Wakalah bi Al-Ujroh dalam Industri Asuransi dan Lembaga Keuangan Syariah Lainnya. Jurnal Ekonomi Dan Hukum Islam, 2(1), 90-111.

Rahmawati. (2011). Dinamika Akad dalam Transaksi Ekonomi Syariah. Al-Iqtishad, III(1), 19-34.

Sahroni, O. (2017). Kupas Tuntas E-Money Menurut Syariah. Indonesia. Retrieved from https://www.youtube.com/watch?v=qggLZOQS87U

Santoso, H., \& Anik. (2015). Analisis Pembiayaan Ijarah Pada Perbankan Syariah. Jurnal Ilmiah Ekonomi Islam, 1, 106-116.

Tim Inisiatif BI 2006. (2006). Upaya Meningkatkan Penggunaan Alat Pembayaran Non Tunai Melalui Pengembangan E-Money. Bank Indonesia. 